\section{Grand challenges and global solutions: where does injury prevention fit in?}

\author{
Roderick J McClure
}

While the burden of injury is large, injury does not feature on most people's list of global grand challenges-climate change, equity, ageing, racism, human rights, poverty, COVID-19. Each person's 'grand challenge list' is different. What is yours? Does injury feature?

As an injury prevention researcher, how do I make sense of a list of global grand challenges that does not include injury? As a practitioner, how can I achieve influence in a world that does not recognise injury as an important problem?

There has been a tendency to explain the importance of injury prevention by highlighting the burden of injury then fragment the overall problem into its components (road safety, falls, drowning, etc) before developing countermeasures to address the burden.

Rather than distinguishing a fragment of the injury problem and then working to address it, would we not achieve a greater reduction in injury, if instead, we worked on poverty, human rights, racism, equity and climate change-from an injury prevention perspective? To what extent does our traditional focus on aspects of the injury problem reduce our ability to see factors at the larger level that might explain the distribution of risk factors for which we are developing countermeasures?

While at first glance, the world's grand challenges look like a mixed bag, closer examination reveals them to be very much

Correspondence to Dr Roderick J McClure, School of Rural Medicine, University of New England, Armidale, New South Wales, Australia; rmcclure@une.edu.au of a single class. They are all issues of societal function. Is injury prevention any different? The road crash epidemic of the last 100 years is a direct consequence of the way society has organised its mobility systems. ${ }^{1}$ House fires across the world caused by paraffin use in the home are a direct consequence of the way we prioritise and organise the distribution of energy to communities. ${ }^{2}$ Injury too is a product of societal function.

Could we envisage an approach to injury prevention that harnesses the collective will of nations to collaborate on efforts to minimise harm caused by the way we organise our societies? Think about your list of top 10 global grand challenges. What is the nature and extent of the injury problem involved in each? How are the risk factors for injury distributed across the various elements and relationships entailed in your chosen issues? What are the challenging solutions that can be implemented and what reduction in injury will result? Most importantly perhaps, how can we apply what we know about injury prevention to help our global community develop solutions to address well-being outcomes across the full range of human concerns.

Here is a specific challenge to readers of Injury Prevention. I invite you to frame a submission to the journal that advances the science of injury prevention in relation to the grand challenge theme. Authors are encouraged to seek formative guidance from the editor as to the scope and suitability of their proposed submission, thence follow usual online submission processes for their chosen manuscript category.

Funding The authors have not declared a specific grant for this research from any funding agency in the public, commercial or not-for-profit sectors.

Competing interests None declared.

Patient and public involvement Patients and/or the public were not involved in the design, or conduct, or reporting, or dissemination plans of this research.

Patient consent for publication Not required.

Provenance and peer review Not commissioned; internally peer reviewed.

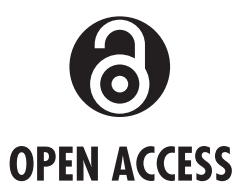

Open access This is an open access article distributed in accordance with the Creative Commons Attribution Non Commercial (CC BY-NC 4.0) license, which permits others to distribute, remix, adapt, build upon this work non-commercially, and license their derivative works on different terms, provided the original work is properly cited, appropriate credit is given, any changes made indicated, and the use is non-commercial. See: http://creativecommons.org/ licenses/by-nc/4.01.

(C) Author(s) (or their employer(s)) 2021. Re-use permitted under CC BY-NC. No commercial re-use. See rights and permissions. Published by BMJ.

(D) Check for updates

To cite McClure RJ. Inj Prev 2021;27:399.

Inj Prev 2021;27:399.

doi:10.1136/injuryprev-2021-044400

ORCID iD

Roderick J McClure http://orcid.org/0000-0002-90678282

\section{REFERENCES}

1 McClure RJ, Adriazola-Steil C, Mulvihill C, et al. Simulating the dynamic effect of land use and transport policies on the health of populations. Am J Public Health 2015;105 Suppl 2:S223-9.

2 Kimemia D, Van Niekerk A, Seedat M. Paraffin dangers, health and socioeconomic consequences: urgent need for policy action. S Afr Med J 2020;111:17-19. 